ICACCG2020 30-31 July, 2020, Ansal University, Gurgaon, India

International Journal of Technical Research \& Science (Special Issue) ISSN No.:2454-2024 (online)

\title{
DAYLIGHT PERFORATION INTO THE INTERIOR SPACES OF THE VERNACULAR HAVELI OF BIKANER
}

\author{
Tanaya Verma ${ }^{1}$, Dr.Tejwant Singh Brar ${ }^{2}$ \\ E-Mail Id: ${ }^{1}$ tanayaverma221@gmail.com, ${ }^{2}$ brartejwant @yahoo.com \\ Sushant School of Art \& Architecture, Ansal University, Gurgaon, Haryana, India
}

\begin{abstract}
Vernacular architecture based on bioclimatic concepts was developed and used through the centuries by many civilizations across the world. Bikaner is a non-basin settlement in the hot and dry climatic region of India and cooling is the single main agenda for habitation as the temperature is very harsh. The vernacular architecture of the Bikaner Haveli's has provided a comfortable shelter against the harsh climatic conditions of the region. Solar radiation is very harsh and the region has the maximum number of sunny days. A survey of residential haveli's, more than 100 years old was carried out in the walled town of Bikaner. The objective of the investigation was to understand the daylight penetration into the interior spaces of the haveli. And also how intelligent architecture protects the interior spaces from excessive hear gain.
\end{abstract}

Keywords: Daylight, Vernacular Architecture, Thermal Comfort.

\section{INTRODUCTION}

As the phrase goes "Change is the only constant", we have seen the impact of the current technological advances have affected the human race the most. The limitation in naturally available material and primitive construction system constrained earlier construction development. The design of shelter and the lifestyle of people depended on the immediate surrounding. Daylight is the main source of light and energy available to mankind. Sunlight also brings in the heat along with it. The clever architectural design can help in controlling the sunlight penetration into the interior spaces with minimizing heat gain because of sunlight. The vernacular architecture provides an excellent example on hoe to harness sunlight for its advantage and also create a thermally comfortable living space.

\section{VERNACULAR ARCHITECTURE}

"Building that belong to a place, that expresses the local or regional dialect" [1]

The origin of the word 'vernacular' finds its roots in the Latin word 'vernaculus' the meaning of which is native, domestic, indigenous or that which is indigenous of the local people. Vernacular can be said as the indigenous manifestation of local climate, geography, materials, customs and traditions of the people. If we look at the works of Rudofsky, Amos Rapoport and Paul Oliver on their concepts and understanding for the vernacular they have very correctly described by Rudofsky the term vernacular in the context of the architecture and it can be called as vernacular, anonymous, indigenous or rural. Environmental behaviourist Amos Rapoport cites that architects build only about 5\% of dwellings, and the rest are indigenous architecture. Works of Paul Oliver 1960 "Shelter and Society" (1969) \& Ammos Rapport's "House form and Culture" (1969) studies begin to emphasize less the beauty of the vernacular types and more the environmental technological, and social contexts in which they build. Vernacular architecture responds to the region and the social structure of the place. The rich architecture of the natives is like an open book it gives us clues on the rich culture, customs and traditions, philosophy of the local people the occupation and the socio-economic standing. As we study the various vernacular styles of the world, we see the distinct variations based on the location, need and climate of the place. The planning of the dwellings reveals the social and family structure of the place. Climatic design lessons are learned from observation of the long tradition of vernacular architecture [2]. In the book "House form and Culture" (1969) by Ammos Rapport and by Paul Oliver in his book "Shelter and Society" in 1960 has talked about the vernacular dwelling are more environmentally, and in tune with the context be it in terms of social, cultural context or the landscape they are built-in. As considered in bioclimatic approach, the Human stands as the central measure in architecture, surrounded by human physical and psychological reactions to the physical (luminous \& sonic), environmental (climatic), and elemental (special \& animate) [3].

\section{HAVELI ARCHITECTURE}

The courtyard typology can be observed in many parts of the world Asia, middle east, or the Mediterranean, and the courtyard provided the natural light and ventilation to the living quarters around it. The courtyard also acted as the central hub for all the religious and cultural activities of the household. The typology has endured centuries of developmental transformation because of the contextual and behavioural change in society [4]. Parmar gave the idea that the urban courtyard form developed from the rural village house. The haveli typology was a product of the prevalent condition of the society and also became a status symbol for its owner. The haveli could be a single-storied to a double or even a four-storied structure. The Havelis in India date from as early as the 1600s to the early 20th century [5]. 
ICACCG2020 30-31 July, 2020, Ansal University, Gurgaon, India

International Journal of Technical Research \& Science (Special Issue) ISSN No.:2454-2024 (online)

\subsection{Haveli's of Bikaner}

"If dreams are cast in stone and if stones can sing they would be like the exterior and interior of Bikaner Haveli's .Aldous Huxley

These are the word used by eminent philosopher and author to describe the beauty of Bikaner Havelis. The term 'Haveli' is of uncertain origin, with various dictionary definitions, but amongst the alleys of north Indian towns its use suggests a distinguishable type of inward-looking, urban courtyard house, and signifies a way of life, based on traditions, and patterns of etiquette and behaviour, that was more than just a form of architecture [6]. The word Haveli has its origin in "haowala" meaning partition in Arabic [7]. The other definitions for the Haveli are mansion built around at least one courtyard [8] or as said by Parmar as a large mansion [9]. Haveli just cannot be described by its physical structure, and the Haveli is much beyond the spacial layout and the ornamentation. As mentioned in a brochure, a social definition fits best. The Haveli is a mansion, which symbolizes generation who articulated their lifestyle that includes architecture, customs and manners, of course, arts, crafts and music. [10]

The small town of Bikaner boats of around 1000 plus Havelis some large some small, spread around the walled city along the narrow lanes. Most of the Havelis are of the merchant families, generally the Marwaris. The mawaris showed their affluence by constructing many Havelis across towns where they frequented for trade [11]. The Haveli is adorned with beautiful artwork be it fresco, mural, wooden and stone carving giving a glimpse of its rich cultural past. A typical haveli is an enclosed majestic piece of architecture, it does not depend if it is large or small in scale, but all have a distinct character to it. The Haveli may look imposing on the narrow streets by the access is through ta small gateway through a flight of steps climbing up from the street. The Haveli's sit together tightly embedded on the street with similar adjoining Havelis, and together they form one seamless façade on the street. It becomes difficult to distinguish where one haveli starts and the ends. It is only by the distinct ornamentation and façade treatment that one makes out or identifies the Havelis as seen in Fig. 3.1.

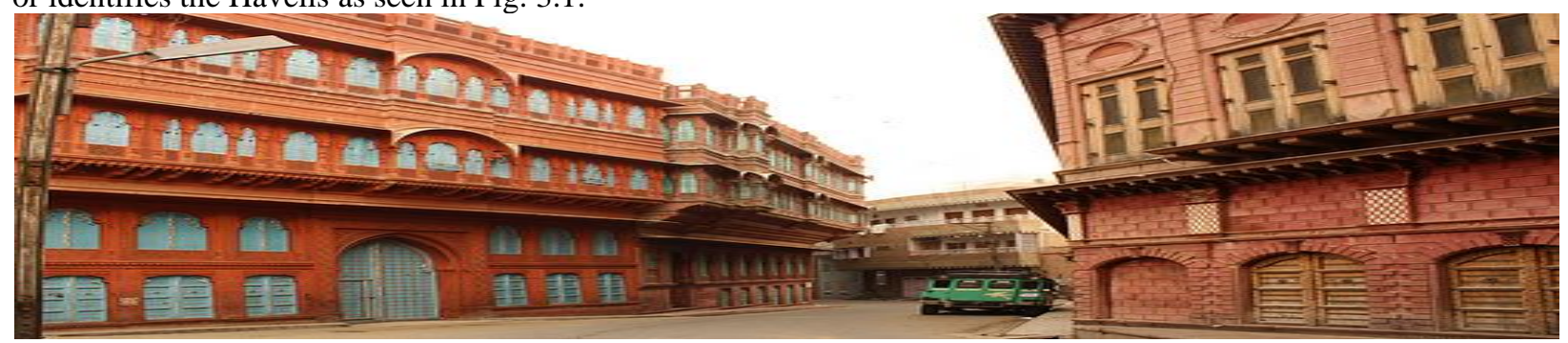

Fig. 3.1 Haveli Façade

The chabotra or the raised platform or it can also be called as the veranda space is a place for resting used by the men folks. The upper floor balcony, which has low railing, is used by the women to view the city street and the hustlebustle of the neighbourhood. The women are thus protected and cannot be viewed by the public. The entrance is small, and it leads to the small internal rooms which are generally used for meeting outsiders by the men. This space is also used as a small office space for carrying out day to day transaction. As most of the people are money lenders, jewellers or traders.

The typical Havelis of Bikaner have one central courtyard, around which the entire household is laid out. The baithak is the front portion of the Haveli, which was used for their daily work-related interactions, and the accountant would be using this space. The courtyard is the most crucial element of the house. The courtyard is planned first while deciding the construction and layout of the Haveli. The size and proportion of the courtyard is the deciding factor as it reflects for the size of the plot and the size of the Haveli. The house plan concentrically evolves around the courtyard. The courtyard is the main central hub of the Haveli, it the place which sees activity throughout the day. The courtyard is the social center of the house. The central courtyard is not very big in Bikaner to protect the interior from the harsh solar rays. The typical plan of the haveli in relation to the street and the central courtyard is shown in Fig. 3.2.

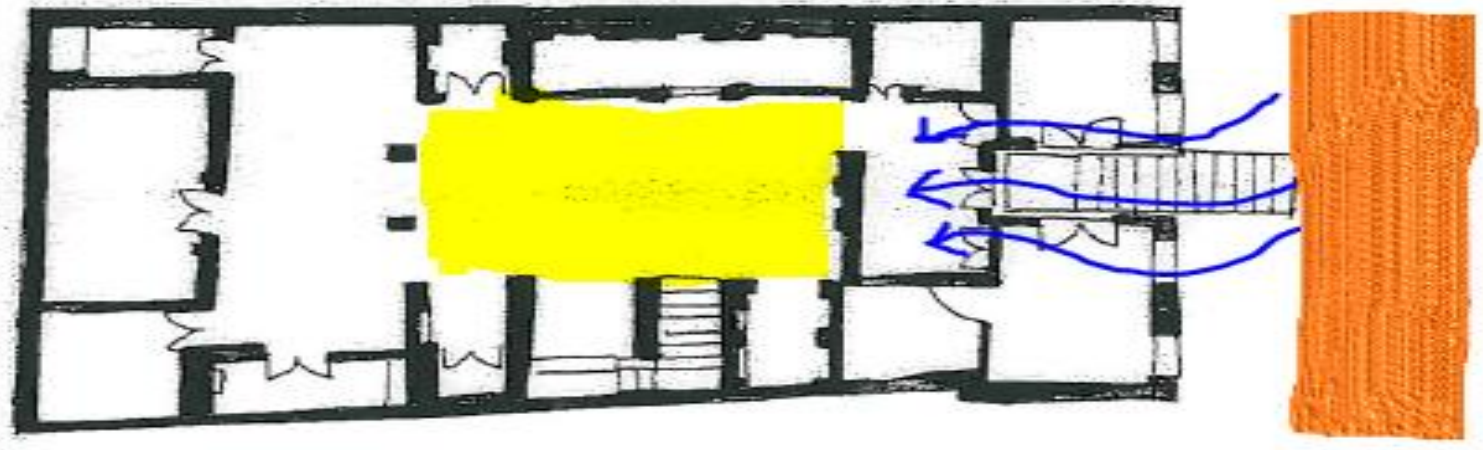

Fig. 3.2 Typical Haveli Plan

DOI Number: https://doi.org/10.30780/specialissue-ICACCG2020/008

Paper Id: IJTRS-ICACCG2020-008

pg. 6

@ 2017, IJTRS All Right Reserved, www.ijtrs.com 
ICACCG2020 30-31 July, 2020, Ansal University, Gurgaon, India

International Journal of Technical Research \& Science (Special Issue) ISSN No.:2454-2024 (online)

\section{BIKANER CLIMATE}

On the climate classification chart, Bikaner falls under the hot-dry zone. The climate zone is spread across the west and central zone of India. The hot-dry region is usually devoid of much vegetation due to the harsh temperature and low humidity. The major cities in this region are Jaisalmer, Jodhpur and Bikaner that experience such type of climate. We also observe that the region is relatively flat and sandy; the winds are moderate to vigorous in intensity. There are few to non-water sources in this region, and the availability of groundwater is low, making water a very scarce commodity. The annual precipitation is less than $500 \mathrm{~mm}$. Solar radiation is high rendering the surface to be dry as it is devoid of any moister hardly any vegetation grows in this region. The maximum temperature in summer day is between $40^{\circ} \mathrm{C}-45^{\circ} \mathrm{C}$, and on the other hand the night temperature is around $20^{\circ} \mathrm{C}-30^{\circ} \mathrm{C}$. in winters the temperature is maxing in the range of $5^{\circ} \mathrm{C}$ to $25^{\circ} \mathrm{C}$ and the night temperature falls to $0^{\circ} \mathrm{C}$ to $10^{\circ} \mathrm{C}$, as it is noticed that the diurnal temperature variation is very high. The sky is mostly clear, and there is ample sunshine.

The hot-dry region thus poses many challenges in the design of the built environment. The biggest issue is to control the ingress of solar radiation. The exposure to the sun is the most critical reason for heat gain in the interior spaces. Careful design intervention is required to control solar radiation. The various methods to control the sun and its heat are as follows

$>$ Effective shading design.

$>$ Reducing surface exposure to the sun, this can be achieved by careful orientation, mutual shading.

$>$ Manage natural ventilation in the interior space.

$>$ Selection of material

$>$ Increasing the thermal capacity of the construction, this helps in providing sufficient thermal lag.

\subsection{Psychrometric Chart}

Bikaner has only $21 \%$ comfortable and the remaining $79 \%$ hours in the discomfort range. Many times the discomfort is experienced due to high relative humidity in the air when temperatures are also high. In Bikaner, this situation of high temperature and humidity is experienced for a few days of the year. Humidity is relatively low due to lack of any perineal water source. It is observed that thick wall construction, shaded corridors, control of air into space help in maintaining thermal comfort conditions in the enclosed space. In the case of Bikaner, the whole emphasis is on protection from solar radiation as this is the main cause of discomfort. The daily diurnal variation required to be addressed as well the seasonal high to low requires the architectural design provide thermal comfort to its inhabitants as seen below in fig. 4.1. The critical aspect for the discomfort is solar exposure. The understanding of climate and solar geometry give valuable clues on how to design the Havelis to minimize solar penetration.

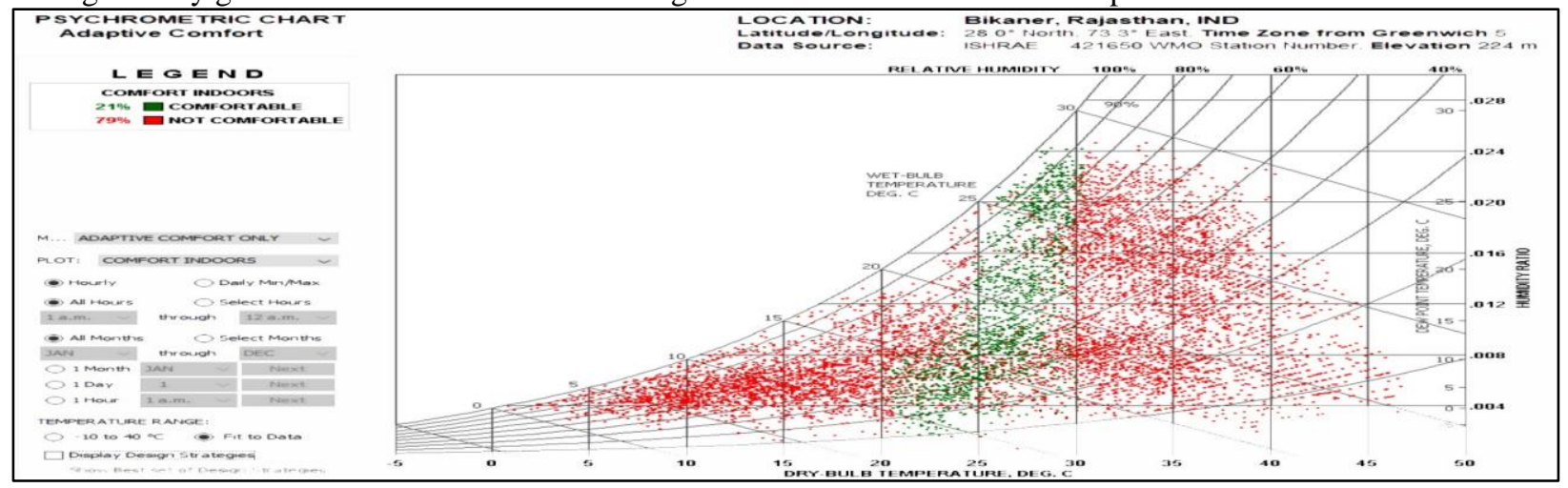

Fig 4.1 Psychrometric Chart - Bikaner (Energy Design Tool, 2017)

\section{SOLAR PENETRATION INTO BUILT FORM}

According to SP:41 guidelines, daylight Factor is the measure of the total daylight illumination at a point and expressed as the ratio or percentage. Daylight Area is the area illuminated not less than the daylight factor for the specified day. Sun is the perpetual source of daylight which the earth receives. The daylight consists of two-component direct solar radiation and the sky component. For daylight design, only the sky component is considered. The amount of sky radiation received for India taken at 8000 lux. Sky Component is the daylight illumination directly received from the sky, and this is the primary source of illumination. [12]

The daylight factor is a measure of all the daylight reaching on an indoor surface from the following point.

$>$ The direct sky visible from the point

$>$ External Surfaces reflecting light to the indoor surface

$>$ Internal surface reflecting light to the point.

The total day-lit area in the haveli (Direct sunlight, External reflection and Internal Reflection) through the central courtyard and the street depends on the size of the courtyard and width of the street and the altitude angle of the Sun. It also depends on the height and width of the fenestration as shown in Fig. 5.1.

DOI Number: https://doi.org/10.30780/specialissue-ICACCG2020/008

pg. 7

Paper Id: IJTRS-ICACCG2020-008

@ 2017, IJTRS All Right Reserved, www.ijtrs.com 
ICACCG2020 30-31 July, 2020, Ansal University, Gurgaon, India

International Journal of Technical Research \& Science (Special Issue) ISSN No.:2454-2024 (online)
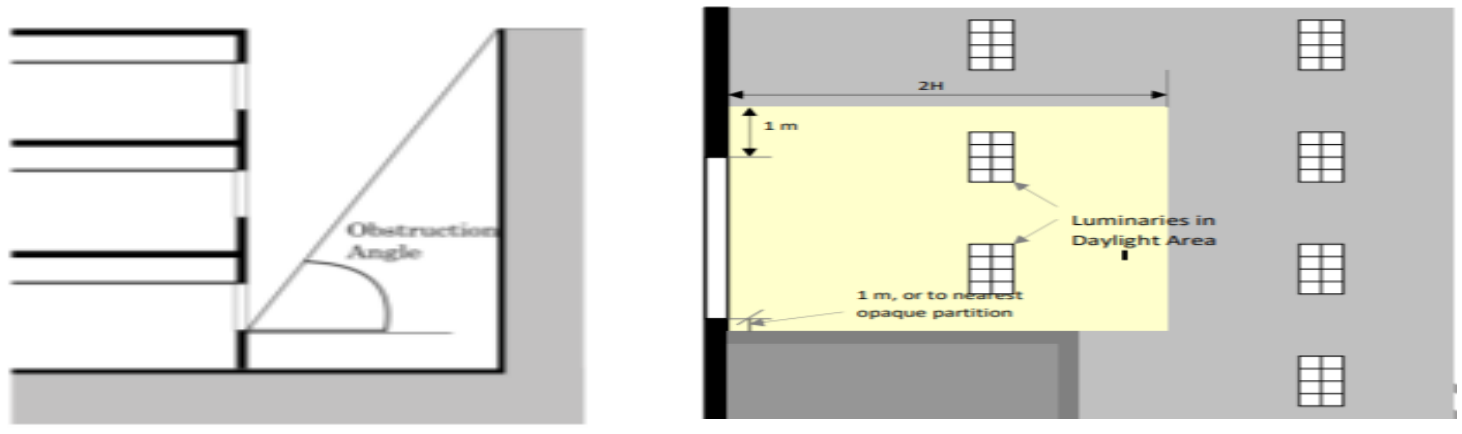

Fig. 5.1 Effective aperture and Daylight Area

In light of the above explanation, the Havelis of Bikaner have the central courtyard size in a range of $3.0 \mathrm{~m}$ to $3.5 \mathrm{~m}$. Also, the street width is 3.0, which gets reduced at the first-floor level onwards due to the overhanging projections. The height of the Haveli above the street level is 3 floors (Ground +2 floors). Thus the width of the street and the courtyard to building height is 1:3 (courtyard) and 1:4 (street), so the effect of mutual shading effect and the direct Sunlight penetration in the courtyard as well as direct sunlight in the haveli from the street side fenestration [13]. In respect to this built form for study of daylight area into the interior spaces the solar altitude angle of $45^{\circ}\left(\tan 45^{\circ}=1.0\right)$, $60^{\circ}\left(\tan 60^{\circ}=1.75\right)$ and $72^{\circ}\left(\tan 72^{\circ}=3.0\right)$ are studied. When the Sun is less than $45^{\circ}$ there is no solar penetration in the interior spaces even on the second-floor level. When the Sun reaches an altitude of $45^{\circ}-60^{\circ}$ solar penetration is equal to the height of the floor into the second-floor interior spaces both from the courtyard and the street. At the solar altitude of $60^{\circ}$ the sun reaches the first floor both from the courtyard and the street. And when the solar altitude reaches $72^{\circ}$ the sun reaches the veranda adjoining the courtyard and the street, for solar altitude above $72^{\circ}$ the direct sun reaches the courtyard and also the street. Sky component is also affected by the height to width ratio of the courtyard and the street. Sky component is maximum on the second floor at $30 \%$ and reduces to $15 \%$ as it reaches the first floor further reduces to $5 \%$ at the ground floor level [14] [15].

\subsection{Daylighting and Solar Penetration}

As observed in the above section, Bikaner has minimum sky cover, and this interprets in a maximum number of sunny days. The intense solar radiation experienced in Bikaner requires an architecture which minimizes the solar penetration into the interior spaces and in this process reduce the heat gain also. To understand the relationship between the sum and the built form, it is important to understand the various influencing factors. Also, daylight is the main source of illumination for the day, and all the household activities are bounded by it.

\subsection{Daylight Requirement}

The daylight factor to be maintained in any interior space is specified concerning external illumination. The daylight in the interior spaces for various tasks are taken based on the sky component is easily determinable. The recommended illumination as per SP 41 for Interior spaces and tasks are given below [12]. The minimum lux levels for performing any household work is given above. It is observed that the courtyard is the main central hum of the household in the vernacular haveli. It is the place for family gathering and also the place where all household activities are performed. This is also seen because the illumination level in the rooms of the haveli are below the required level for any specific task to be comfortably performed. As the interiors are dark, they also remain comparatively cool as this is no solar penetration into these spaces. The haveli can be divided into levels the Basement, Lower ground floor, Upper Ground Floor, First Floor and the Second Floor. The courtyard is at the upper ground floor level. Below is the table which gives the solar angle throughout the year. The table below looks at the solar penetration throughout the year in a vernacular haveli at Bikaner. The duration of days where the sun penetrates into the built indoor space is mapped based on the solar movement chart using the software and validating the same during case study on-site.

Table-5.1 Recommended Values of Illumination [12]

\begin{tabular}{|l|l|}
\hline Location & Lux \\
\hline Kitchen & 200 \\
\hline Living room & 50 \\
\hline Study & 152 \\
\hline Circulation & 25 \\
\hline Bathroom & 100 \\
\hline
\end{tabular}


ICACCG2020 30-31 July, 2020, Ansal University, Gurgaon, India

International Journal of Technical Research \& Science (Special Issue) ISSN No.:2454-2024 (online)

\begin{tabular}{|l|l|}
\hline Stairs & 100 \\
\hline Workshops & 200 \\
\hline Garages & 70 \\
\hline Sewing and darning & 700 \\
\hline Reading (casual) & 150 \\
\hline Homework and sustained reading & 300 \\
\hline
\end{tabular}

Table 5.2: Duration of Days and Solar Penetration

\begin{tabular}{|c|c|c|c|c|c|}
\hline \multirow[t]{2}{*}{$\begin{array}{l}\text { Duration Days of } \\
\text { the Year }\end{array}$} & \multirow[t]{2}{*}{$\begin{array}{l}\text { Solar } \\
\text { Angle }\end{array}$} & \multicolumn{3}{|c|}{$\begin{array}{l}\text { Duration (Hrs) of Solar } \\
\text { Penetration }\end{array}$} & \multirow[t]{2}{*}{ Remark } \\
\hline & & $\begin{array}{l}\text { Ground } \\
\text { Floor }\end{array}$ & $\begin{array}{l}\text { First } \\
\text { Floor }\end{array}$ & $\begin{array}{l}\text { Second } \\
\text { Floor }\end{array}$ & \\
\hline $\begin{array}{l}9 \text { Nov-3 Feb } \\
(22 \text { Dec) }\end{array}$ & $<45^{0}$ & $\begin{array}{l}\text { Zero } \\
\text { Hours }\end{array}$ & $\begin{array}{l}\text { Zero } \\
\text { Hours }\end{array}$ & $\begin{array}{l}\text { Less than } \\
5 \text { min }\end{array}$ & $\begin{array}{l}\text { The direct sun only reaches the second } \\
\text { floor. Penetration is equal to the height of } \\
\text { the floor. }\end{array}$ \\
\hline $\begin{array}{l}27 \mathrm{Sept}-8 \mathrm{Nov} \\
(10 \mathrm{Oct}) \\
4 \mathrm{Feb}-15 \mathrm{Mar} \\
(19 \mathrm{Feb})\end{array}$ & $\begin{array}{l}45^{0}- \\
60^{0}\end{array}$ & $\begin{array}{l}\text { Zero } \\
\text { Hours }\end{array}$ & $\begin{array}{l}10.30 \text { to } \\
14.20\end{array}$ & $\begin{array}{l}10.00 \text { to } \\
10.30 \\
\& 14.20 \\
\text { to } 14.50\end{array}$ & $\begin{array}{l}\text { The direct sun reaches till the first floor. } \\
\text { Penetration is equal to half the height of the } \\
\text { floor. } \\
\text { The direct sun only reaches the second } \\
\text { floor. Penetration is equal to the height of } \\
\text { the floor. }\end{array}$ \\
\hline $\begin{array}{l}\text { 26Aug - 26 Sept } \\
\text { (10 Sep) } \\
16 \mathrm{Mar}-15 \mathrm{Apr} \\
\text { (31 March) }\end{array}$ & $60^{0}-72^{0}$ & $\begin{array}{l}\text { Less than } \\
5 \text { min in } \\
\text { the } \\
\text { Veranda }\end{array}$ & $\begin{array}{l}9.55 \text { to } \\
11.55 \& \\
13.55 \text { to } \\
15.15\end{array}$ & $\begin{array}{l}9.30 \text { to } \\
9.55 \& \\
15.15 \text { to } \\
15.40\end{array}$ & $\begin{array}{l}\text { The direct sun reaches the ground floor } \\
\text { veranda } 1 / 3 \text { the height of the floor height } \\
\text { The direct sun reaches till the first floor. } \\
\text { Penetration is equal to half the height of the } \\
\text { floor. } \\
\text { The direct sun only reaches the second } \\
\text { floor. Penetration is equal to the height of } \\
\text { the floor. }\end{array}$ \\
\hline $\begin{array}{l}\text { 16 Apr }-25 \text { Aug } \\
\text { (21 June) }\end{array}$ & $>72^{0}$ & $\begin{array}{l}10.30 \text { to } \\
14.50 \text { in } \\
\text { the } \\
\text { courtyard }\end{array}$ & $\begin{array}{l}9.20 \text { to } \\
10.30 \& \\
14.50 \text { to } \\
16.00\end{array}$ & $\begin{array}{l}9.00 \text { to } \\
9.20 \& \\
16.00 \text { to } \\
16.20\end{array}$ & $\begin{array}{l}\text { The direct sun reaches the ground floor } \\
\text { veranda } 1 / 3 \text { the height of the floor } \\
\text { The direct sun reaches till the first floor. } \\
\text { Penetration is equal to half the height of the } \\
\text { floor. } \\
\text { The direct sun only reaches the second } \\
\text { floor. Penetration is equal to the height of } \\
\text { the floor. }\end{array}$ \\
\hline
\end{tabular}

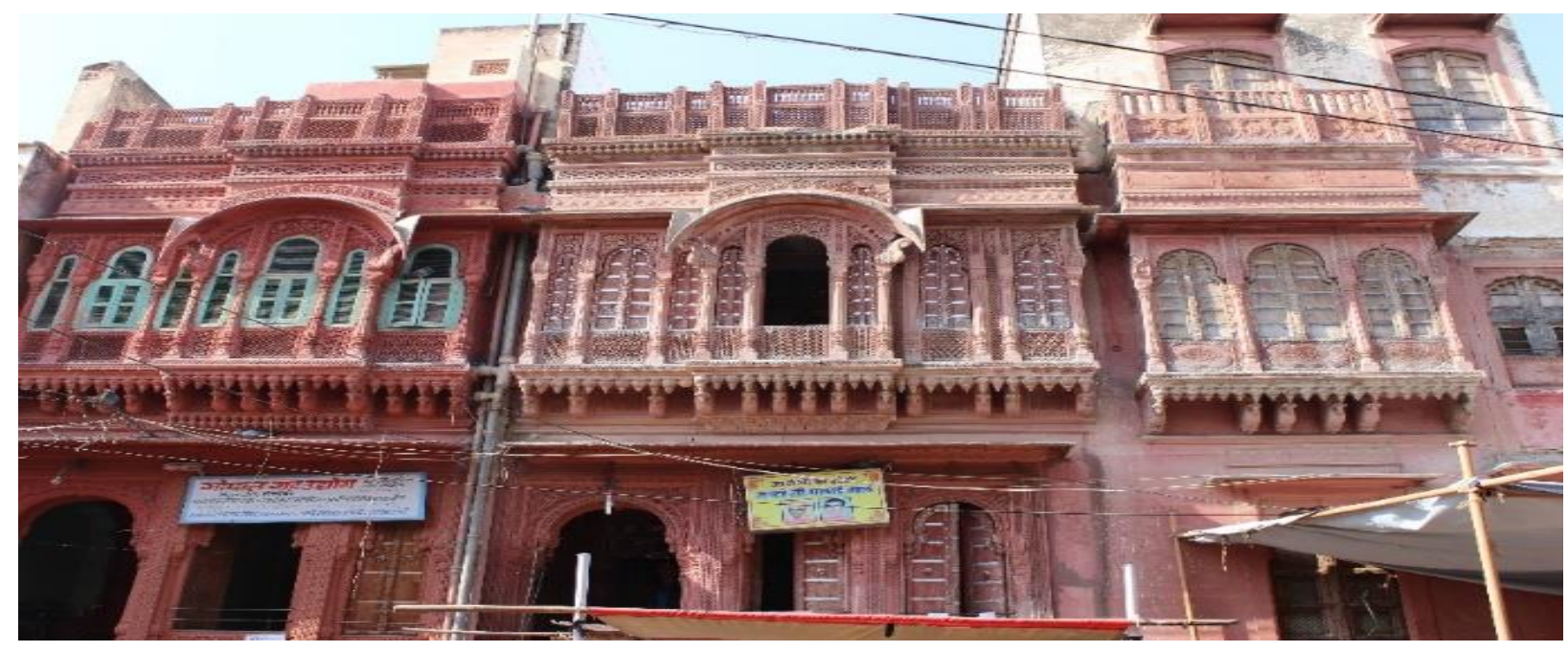

Fig. 3.2 Front Facade of the Haveli

DOI Number: https://doi.org/10.30780/specialissue-ICACCG2020/008

Paper Id: IJTRS-ICACCG2020-008

pg. 9

@ 2017, IJTRS All Right Reserved, www.ijtrs.com 
ICACCG2020 30-31 July, 2020, Ansal University, Gurgaon, India

International Journal of Technical Research \& Science (Special Issue) ISSN No.:2454-2024 (online)

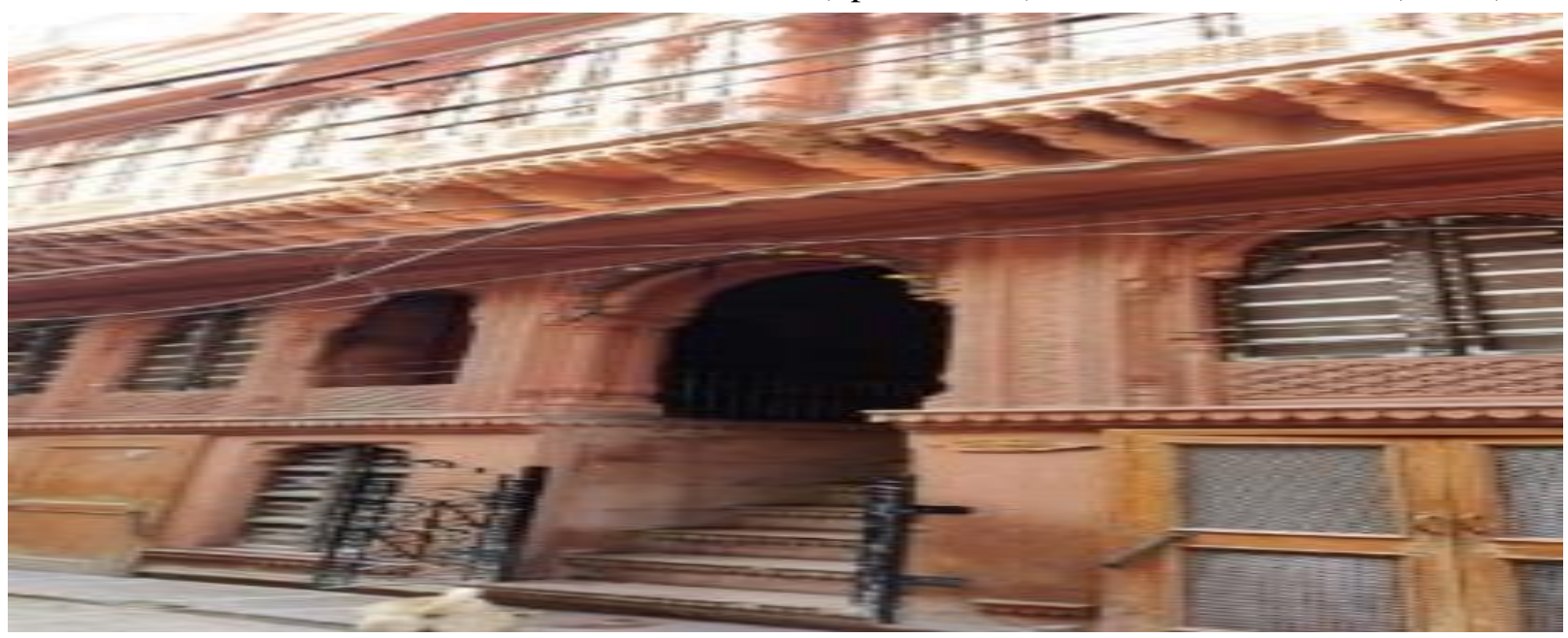

Fig. 5.3 Overhanging first floor of the Haveli

As observed in Fig. 5.3, the first floor is overhanging on the street and protects the ground floor. The solar angle does not reach the ground level due to the dense urban composition. As seen in Figure 5.2 the front façade and how desnsly the urban fabric is created. This results in reducing the solar exposure to the external faces. The urban form is also seen in Fig. 5.4.

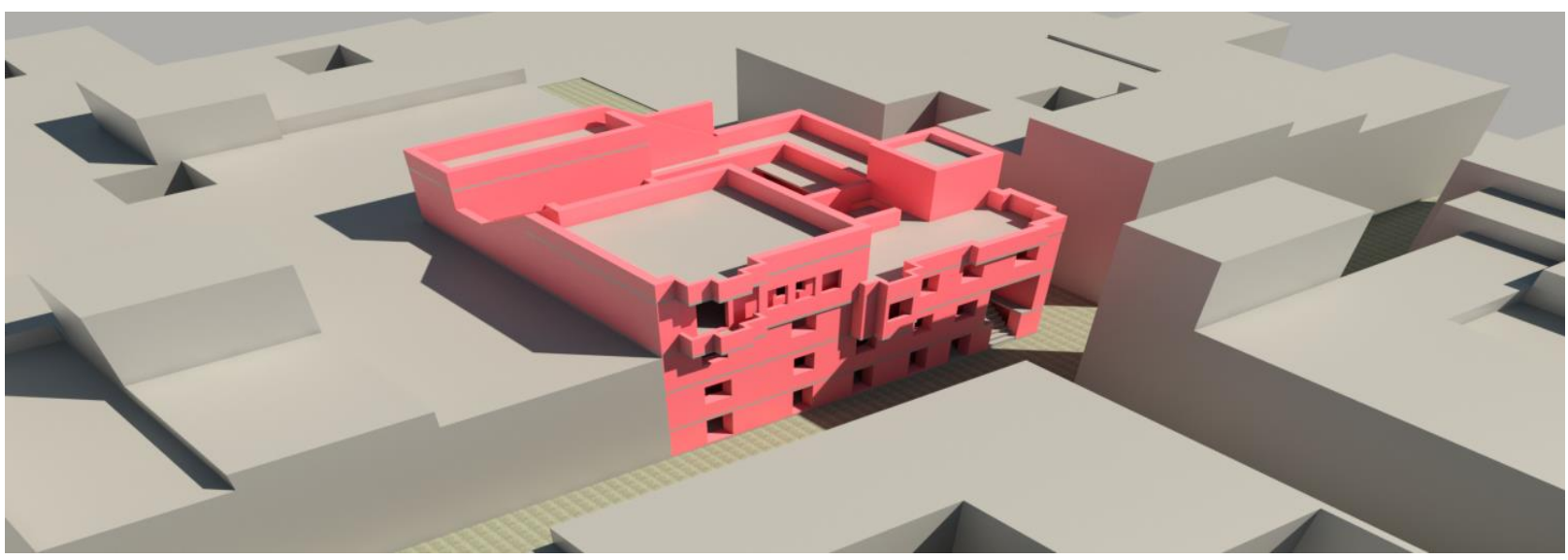

Fig. 5.4 Urban Ccomposition of Narrow Sstreets and Compact Havelis

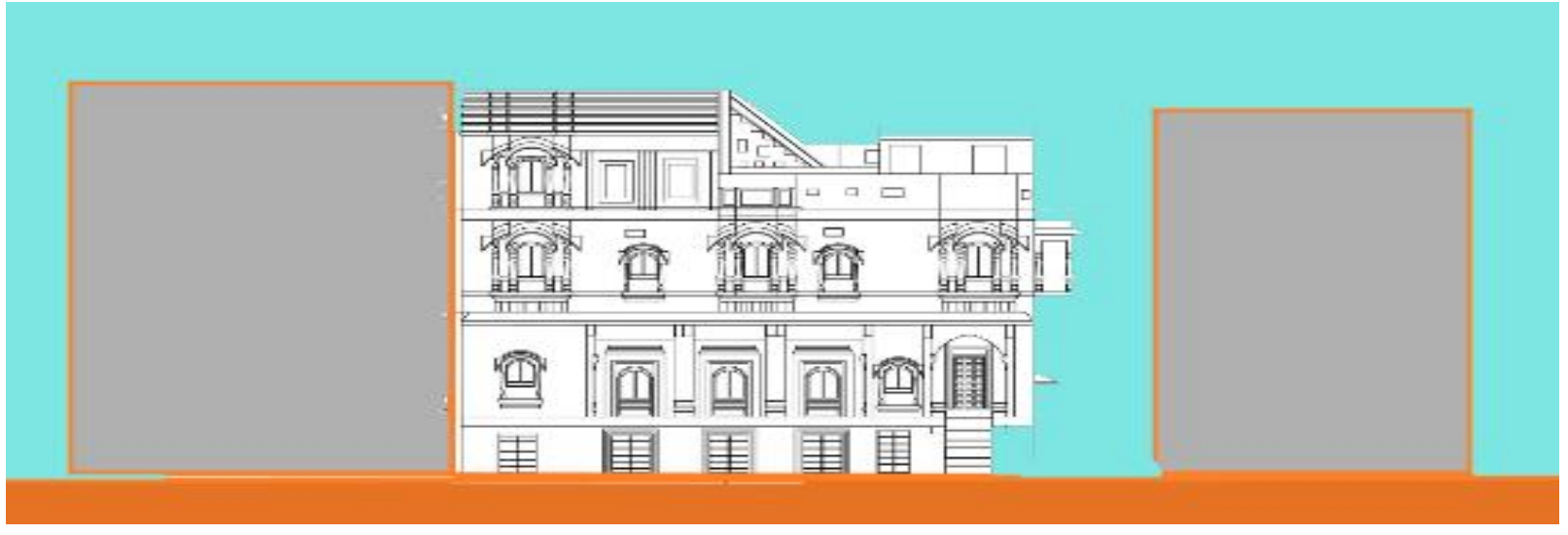

Fig. 5.5 Street Section

The penetration of direct suns rays is dependent on the openings in the Haveli. The courtyard is the main central opening which provides light and ventilation into the interior spaces of the haveli. The street is also from where the front façade of the haveli has access to sunlight and ventilation. The understanding of the geometry of both these spaces is important to for solar study.

In the haveli, the courtyard is on the upper ground floor and is surrounded by built form on all the sides. The width of the courtyard is $3.5 \mathrm{~m}$ to $3.0 \mathrm{~m}$, and the height of the built mass around it is 11 to 13 meters. The courtyard is surrounded by corridors which have a depth of $2.4 \mathrm{~m}$ to $1.8 \mathrm{~m}$. The rooms open into the corridor. The source of light and ventilation 
ICACCG2020 30-31 July, 2020, Ansal University, Gurgaon, India

International Journal of Technical Research \& Science (Special Issue) ISSN No.:2454-2024 (online)

into the rooms is through the corridor only by way of the doors and in some bigger room, which also has a window which opens into the corridor. The solar penetration is as specified in. The street composition of the haveli and the courtyard is shown in Fig. 5.5 and 5.6.

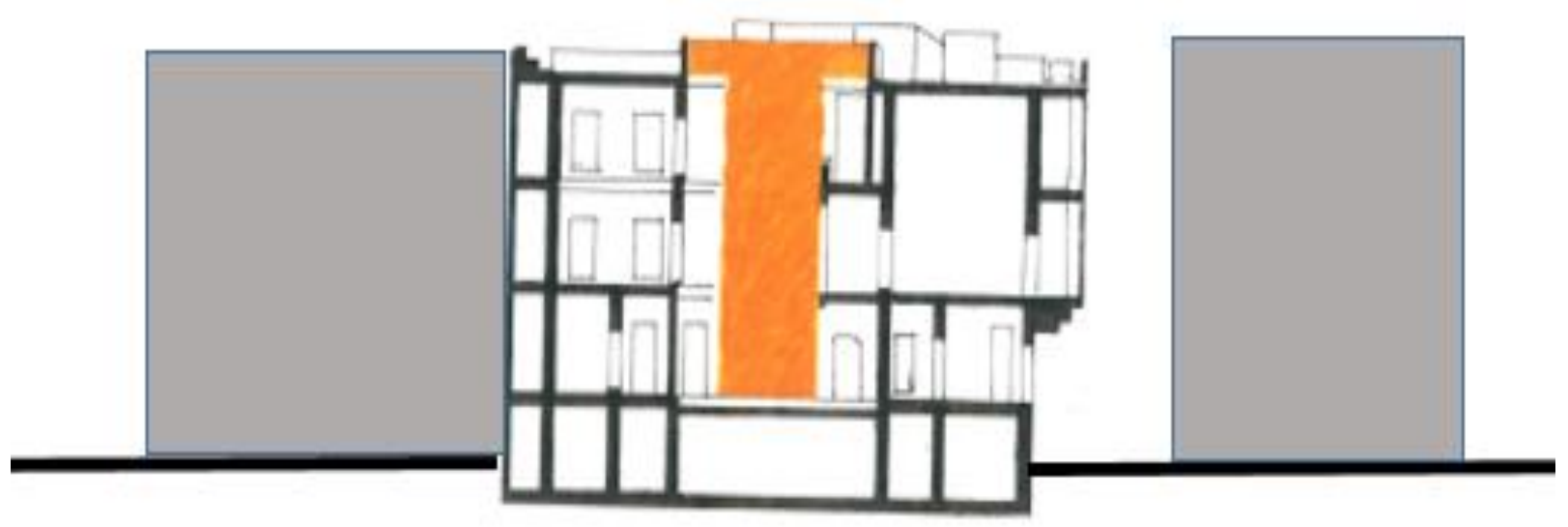

Fig. 5.6 Section with Courtyard and Street

As analysed in Table 5.2 the Haveli is analysed for solar penetration into the built form, courtyard and street. As seen from $9^{\text {th }}$ November to $3^{\text {rd }}$ February, the solar angle is less than $45^{0}$ in this period. The direct solar penetration is for zero hours on the ground level in the courtyard and the street. The direct solar penetration is for a few minutes on the second floor when the solar angle is at $45^{\circ}$. Solar penetration into the interior space is equal to the height of the floor. These months are also the winter months and the temperature in the range of $20^{\circ} \mathrm{C}$ to $-2^{\circ} \mathrm{C}$. The sky component provides illumination. There is no solar penetration at the ground and first floor. The above floor rooms keep the windows open to allow solar penetration into the interior spaces whereas on the ground floor the openings are closed so as to keep the chilled winds from entering indoors.

As seen from $27^{\text {th }}$ September to $8^{\text {th }}$ November and also from $4^{\text {th }}$ February to $15^{\text {th }}$ March, the solar angle is in the range of $45^{\circ}$ to $60^{\circ}$ in this period the direct solar penetration is for zero hours on the ground level in the courtyard and the street. The direct solar penetration is for $4 \mathrm{hr}$ into the first floor, and the penetration depth is half of the floor height. The second floor gets solar penetration from morning $10.00 \mathrm{am}$, and it remains till $14.50 \mathrm{pm}$ the solar penetration is equal to the height of the floor. This is the time period when the winters are setting (Sept to Nov), and the household uses the second floor and the terraces for daily activities. The period of fading winters (Feb to March) also sees and increase activity on the upper floor.

As seen from $16^{\mathrm{h}}$ April to $25^{\text {th }}$ August, the solar angle is more than $72^{0}$ in this period the direct solar penetration is for 4 hours in the veranda next to the courtyard, and the penetration is one third the height of the floor height. The direct solar penetration is for $7 \mathrm{hr}$ into the first floor, and the penetration depth is half of the floor height. The second floor gets solar penetration for 7 hours, and solar penetration is equal to the height of the floor. As these are the extreme summer months (April - August) for these four months, the solar intensity is too harsh and thus heating the built mass. The upper floors which get maximum solar penetration are heated more than the ground floor. The windows are kept closed during these months, and the cloured glass in the window panel allows filtered light into the interior spaces and also keeping the glare outside. The clever use of louvres in the construction of windowpane, which allows ventilation into the interior space still keeping the opening closed. The daily activity shifts to the ground floor; this is cool and comfortable.

The solar intensity and solar angle mapping through the year as in Table 5.2 shows the angle of solar penetration as it changes from month to month. Sky component is the main source illumination for the interior spaces. The first-floor witnesses a reduction of $15 \%$ of the sky component, and on the courtyard level it gets reduced by $30 \%$, resulting in the illumination due to sky component on the ground floor it will be 1.5 times the floor height into the veranda. On the first floor, it is 1.75 times the floor height, and on the second floor, it is two times the floor height for illumination resulting out of sky component.

\section{CONCLUSION}

The solar penetration is controlled into the interior spaces by dense urban geometry, which reduces the exposed surfaces to direct solar rays. The height to width ratio of the open spaces regulates the penetration of direct solar penetration. The architectural form allows illumination due to the sky component which provides adequate illumination to carry out a daily routine.

\section{REFERENCES}

[1] Bonner, Building Tradition: Control and authority in vernacular architecture, Oxon: Taylor \& Francis, 2006.

[2] V. Maria, "Evaluation of a sustainable Greek Vernacular settlement and its landscape: architectural typology and building physic.," Building and Environment, pp. 1095-106, 2009.

DOI Number: https://doi.org/10.30780/specialissue-ICACCG2020/008 
ICACCG2020 30-31 July, 2020, Ansal University, Gurgaon, India

International Journal of Technical Research \& Science (Special Issue) ISSN No.:2454-2024 (online)

[3] O. A. Olgyay V, "Design with climate: bioclimatic approach to architecturalregionalism," vol. 1, pp. 163-74, 1963.

[4] V. S. Parmar, "A Social History of Indian Architecture," Oxford University Press, p. 51, 2005.

[5] Prasad Suanand, The haveli of North India, 1997.

[6] S. Tillostson, Indian Mansions: A Social History of the Haveli, Cambridge: The Oleander Press, 1994.

[7] S. Prasad, The Havelis of North Indian Cities, London: Unpublished study for the Visual Islamic Art Unit of the Royal College of Art, 1987.

[8] C. Ilay, Rajasthan: The Painted Towns of Shekhawati, Ahmedabad: Prakash Books, 1994.

[9] V. S. Parmar, Haveli: Wooden Houses and Mansions of Gujrath, Ahmedabad: Mapin, 1989.

[10] Prince of Wales Museum, Brochure for an exhibition, Mumbai, 1989.

[11] C. J. Tod, Annals and Antiquities of Rajasthan, Motilal Banarsidass, 1971.

[12] Bureau Of Indian Standards, "Guide For Daylight of Buildings," Bureau Of Indian Standards, New Delhi, 1989.

[13] G. K. Johari, "Energy Conservation in Residential Area, Case Study - Amritsar," Gurunanak Dev University, Amritsar, 2002.

[14] I. Acosta, J. Navarro and J. J. Sendra, "Predictive method of the sky component in a courtyard under overcast sky conditions," Solar Energy, 2012.

[15] S. Sharples and D. Lash, "Daylight in Atrium Buildings: A Critical Review," Architectural Science Review, 2011. 